\title{
PERFORMA ITIK LOKAL JANTAN (ANAS PLATHYRYNCHOS) YANG DIBERI PAKAN SUPLEMEN
}

\author{
Wara Pratitis Sabar Suprayogi*, Sudibyo dan Eko Hari Susilo \\ Program Studi Peternakan, Fakultas Pertanian, Universitas Sebelas Maret Surakarta \\ *Corresponding author: warapratitis@staff.uns.ac.id
}

\begin{abstract}
The research was to know the influence of the supplementation lemuru fish oil and L-carnitine on the local male ducks' performance. The cattle used were 96 local male ducks aged 10 days. Research materials were corn, bran, concentrate 144, lemuru fish oil, and L-carnitine. The research design used was Complete Random Design with 3 treatments and 8 repetitions; each repetition contained 4 local male ducks. The treatment consisted of ration control $P 0=$ corn, barn, concentrate and mineral; $P 1=$ corn, barn, mineral and 4\% lemuru fish oil; P2 = corn, barn, concentrate, mineral, $4 \%$ lemuru fish oil and 30 ppm L-carnitine. The investigated modifiers were feed consumption, feed conversion, daily weight increase and Income Over Feed Cost value. Data feed consumption, daily weight increase, feed conversion was analyzed using variance analysis. If there were a concrete influence, further analysis should be conducted using orthogonal contrast. Results showed that the supplementation of lemuru fish oil and $L$-carnitine had a very significant influence $(P<0.01)$ on feed consumption, daily weight increase and feed conversion. Further test results orthogonal contrast showed that the supplementation of lemuru fish oil and L-carnitine could decrease feed consumption, feed conversion and increase daily weight rate $(P<0.01)$ if compared control. Result Income Over Feed Cost showed that treatment with add lemuru fish oil and L-carnitine produced Income Over Feed Cost value higher if compared control. Based on the results of the research, it could be concluded that the supplementation of $4 \%$ lemuru fish oil and 30 ppm L-carnitine in ration could decrease feed consumption and feed conversion, increase daily weight rate, and the IOFC of local male ducks.
\end{abstract}

Keywords: Fish oil supplementation; L-carnitine; Local male ducks; Performance

Cite this as: Suprayogi, W., Sudibya, S., \& Susilo, E. 2017. Performa Itik Lokal Jantan (Anas plathyrynchos) yang diberi Pakan Suplemen. Caraka Tani: Journal of Sustainable Agriculture. 32(1), 35-41. doi: http://dx.doi.org/10.20961/carakatani.v32i1.15932

\section{PENDAHULUAN}

Ransum berperan besar dalam pemeliharaan itik maupun unggas lain, hal ini dikarenakan penyumbang terbesar dalam usaha peternakan, yakni $70 \%$ persen total biaya produksi untuk pengadaan ransum. Salah satu cara untuk menekan biaya ransum adalah menggunakan produk samping berupa penggunaan minyak ikan lemuru yang merupakan sumber asam lemak omega-3, karena mempunyai energi metabolik yang tinggi. Minyak ikan lemuru (Sardinella longiceps) merupakan produk samping dari industri pengalengan ikan lemuru. Pemanfaatannya belum optimal dan berpotensi sebagai sumber asam lemak omega-3 (Estiasih, 1996).
Suplementasi minyak ikan lemuru sebagai sumber energi dan sumber asam lemak merupakan cara yang tepat untuk memenuhi kebutuhan energi ransum serta asam lemak essensial dalam pakan ternak unggas. Kandungan energi yang tinggi diharapkan mampu meningkatkan performa dan meningkatkan fungsi asam lemak tersebut untuk kebutuhan metabolisme dalam tubuh ternak. Senyawa yang dapat membantu metabolisme asam lemak tersebut adalah $L$-karnitin.

$L$-karnitin mempunyai potensi yang baik untuk meningkatkan pertumbuhan dan katabolisme lemak (Chatzifotis dan Takeuchi, 1997). Penambahan $L$-karnitin dalam ransum dapat meningkatkan aksi protein sparing effect dari lemak, sehingga energi dari protein sebagian besar digunakan untuk membentuk sel-sel baru, 
sehingga energi dari protein sebagian besar dapat digunakan untuk pertumbuhan. Pada penelitian terdahulu dengan menggunakan minyak ikan lemuru dan $L$-karnitin yang diaplikasikan pada induk ayam pedaging dapat memperbaiki performa ternak (Abadi et al., 2007).

\section{METODE PENELITIAN}

Ternak yang digunakan dalam penelitian ini adalah itiklokal jantan umur 10 hari sebanyak 96 ekor dengan bobot badan awal 203,013 $\pm 19,86$ g/ekor yang ditempatkan dalam 24 petak kandang litter dengan ukuran panjang, lebar dan tinggi berturut-turut adalah $120 \times 45 \times 50 \mathrm{~cm}$. Setiap unit kandang berisi 4 ekor itik. Bahan untuk sekat tiap kandang terbuat dari bambu dan untuk litter menggunakan sekam padi. Ransum itik disusun berdasarkan rekomendasi SNI (2006) yang dapat dilihat pada Tabel 1. Kandungan nutrien bahan pakan ransum dapat dilihat pada Tabel 2. Susunan ransum dan kandungan nutrient dalam ransum penelitian dapat dilihat pada tabel 3. Kandungan nutrien dalam 100\% dapat dilihat pada tabel 4.

Tabel 1. Kebutuhan Nutrien Itik Umur 1-8 Minggu

\begin{tabular}{lc}
\hline \multicolumn{1}{c}{ Kandungan } & $\begin{array}{c}\text { Kandungan } \\
\text { Nutrien }\end{array}$ \\
\hline Kadar air (Maks) (\%) & 14,0 \\
Protein kasar (Min) (\%) & 18,0 \\
Lemak kasar (Maks) (\%) & 7,0 \\
Serat kasar (Maks) (\%) & 7,0 \\
Abu (Maks) (\%) & 8,0 \\
Kalsium (\%) & $0,6-1,2$ \\
Fosfor total (\%) & $0,6-1,0$ \\
Fosfor tersedia (Min) (\%) & 0,4 \\
Energi Metabolis (Min) & 2700 \\
(Kkal/kg) & \\
\hline
\end{tabular}

Sumber: SNI (2006)

Tabel 2. Susunan Ransum dan Kandungan Nutrien Ransum Penelitian (\%)

\begin{tabular}{lccc}
\hline Bahan ransum & P0 & P1 & P2 \\
\hline Jagung & 29 & 29 & 29 \\
Bekatul & 40 & 40 & 40 \\
Konsentrat & 30 & 30 & 30 \\
Mineral Premix & 1 & 1 & 1 \\
Minyak ikan lemuru & - & 4 & 4 \\
$L$-karnitin & - & - & 0,003 \\
\hline Total & 100 & 104 & 104,003 \\
\hline Kandungan nutrien & & & \\
\hline Energi metabolis (kkal/kg) & 2705,89 & 3037,09 & 3037,09 \\
Protein kasar (\%) & 18,48 & 18,48 & 18,48 \\
Lemak kasar (\%) & 6,04 & 6,36 & 6,36 \\
Serat kasar (\%) & 4,22 & 4,22 & 4,22 \\
Kalsium (\%) & 4,12 & 4,12 & 4,12 \\
Fosfor tersedia (\%) & 0,62 & 0,62 & 0,62 \\
\hline
\end{tabular}

Sumber: hasil perhitungan berdasarkan Tabel 2

Tabel 3. Kandungan Nutrien dalam 100\%

\begin{tabular}{lccc}
\hline Kandungan nutrien & P0 & P1 & P2 \\
\hline Energi metabolis kkal/kg & 2705,89 & 2920,28 & 2920,28 \\
Protein kasar (\%) & 18,48 & 17,77 & 17,77 \\
Lemak kasar (\%) & 6,04 & 6,16 & 6,16 \\
Serat kasar (\%) & 4,22 & 4,06 & 4,06 \\
Kalsium (\%) & 4,12 & 3,96 & 3,96 \\
Fosfor tersedia (\%) & 0,62 & 0,59 & 0,59 \\
\hline
\end{tabular}

Sumber: hasil perhitungan berdasarkan Tabel 3

Catatan: Ca ransum melebihi standart SNI (2006) sebesar 0,6 - 1,2\% 
Desain penelitian yang dipergunakan adalah Rancangan Acak Lengkap (RAL) dengan tiga perlakuan. Masing-masing perlakuan diulang delapan kali dan setiap ulangan terdiri dari empat ekor. Perlakuan yang diberikan adalah sebagai berikut: ransum kontrol $(\mathrm{P} 0)=$ jagung, bekatul, konsentat dan mineral, $\mathrm{P} 1$ = jagung, bekatul, konsentrat, mineral dan minyak ikan lemuru 4\%, $\mathrm{P} 2$ = jagung, bekatul, konsentrat, mineral, minyak ikan lemuru 4\% dan L-Karnitin 30 ppm.

Penelitian dilaksanakan dengan adaptasi pemeliharaan terlebih dahulu selama 1 minggu dan pemberian perlakuan selama 32 hari. Tahap adaptasi pada umur 10 hari dengan itik langsung diberi ransum basal secara ad libitum dan bertahap. Pemberian air minum secara ad libitum.

1. Pelaksanaan Penelitian

Pelaksanaan penelitian ini dilakukan dengan mengamati berbagai peubah performa itik yang meliputi konsumsi ransum, konversi ransum, pertambahan bobot badan harian dan nilai IOFC. Peubah penelitian yang diamati adalah:

a. Konsumsi ransum

Melakukan perhitungan konsumsi harian itik dengan carajumlah ransum yang diberikan dikurangi dengan sisa ransum yang dinyatakan dalam satuan gram.

\section{Konsumsi Ramsum \\ = Jumlah Ransum yang diberikan \\ - Sisa ransum}

b. $\mathrm{PBBH}$

Melakukan penimbangan terhadap itik dan menyatakan dalam g/ekor/hari.

$$
\begin{aligned}
& \text { PBBH gram } \\
& =\frac{\text { Total ransum yang dikonsumsi }}{\text { Hari }}
\end{aligned}
$$

c. Konversi ransum

Melakukan perhitungan konversi ransum dengan cara:

$$
F C R=\frac{\text { Total ransum yang dikonsumsi }}{P B B H}
$$

d. IOFC

Melakukan perhitungan Income Over Feed Cost dengan cara:

$$
\operatorname{IOFC}(R p)=\text { Penerimaan }- \text { Biaya pakan }
$$

Data Income Over Feed Cost dihitung secara manual tidak menggunakan analisis variansi, sementara itu untuk data konsumsi ransum, pertambahan bobot badan harian dan konversi ransum yang diperoleh dalam penelitian ini dianalisis dengan analisis variansi RAL untuk mengetahui adanya pengaruh perlakuan terhadap peubah yang diamati. Apabila analisis variansi berpengaruh nyata, maka dilanjutkandenganuji Kontras Orthogonal (Steel and Torrie, 1995).

\section{HASIL DAN PEMBAHASAN}

Perlakuan Suplementasi minyak lemuru dan $L$ -

\begin{tabular}{|c|c|c|c|c|}
\hline \multirow[b]{2}{*}{ Peubah } & \multicolumn{3}{|c|}{ Perlakuan } & \multirow{2}{*}{$\begin{array}{l}\text { Keterangan } \\
\text { Signifikansi }\end{array}$} \\
\hline & P0 & P1 & $\mathrm{P} 2$ & \\
\hline Konsumsi ransum(g/ekor/hari) & 143,54 & 139,86 & 139,31 & $* *$ \\
\hline PBBH (g/ekor/hari) & 23,85 & 25,22 & 26,48 & ** \\
\hline Konversi ransum & 6,02 & 5,55 & 5,26 & $* *$ \\
\hline IOFC (Rp) & 5084,1 & 6781,7 & 8294,4 & \\
\hline
\end{tabular}
karnitin dalam ransum itik dapat dilihat pada tabel berikut:

Tabel 4. Rata-rata Konsumsi Ransum, PBBH, Konversi Ransum dan IOFC

Keterangan: ${ }^{* *}$ berbeda sangat nyata $(\mathrm{P}<0,01)$

Hasil analisis variansi menunjukkan bahwa suplementasi minyak ikan lemuru dan $L$-karnitin dalam ransum berpengaruh sangat nyata $(\mathrm{P}<0,01)$ terhadap konsumsi ransum. Hasil penelitian menunjukkan konsumsi ransum tertinggi pada itik tanpa perlakuan (P0) yaitu 143,54 g/ekor/hari, sementara itu konsumsi pada perlakuan suplementasi minyak ikan lemuru (P1) dan perlakuan minyak ikan lemuru $+L$-karnitin $(\mathrm{P} 2)$ berturut-turut adalah 139,86 dan 139,31 
g/ekor/hari. Konsumsi P0 lebih tinggi jika dibandingkan dengan P1 dan P2 dikarenakan kandungan energi dalam ransum tanpa perlakuan sebesar 2705,89 ME kcal/kg lebih rendah dari ransum $\mathrm{P} 1$ dan $\mathrm{P} 2$ yang mempunyai kandungan energi sebesar 3037,09 ME $\mathrm{kcal} / \mathrm{kg}$, dengan demikian terlihat bahwa jumlah kandungan energi dalam ransum mempengaruhi tingkat konsumsi ternak. Meningkatnya konsumsi dikarenakan pada umumnya unggas mengkonsumsi ransum untuk memenuhi kebutuhan energi, apabila kebutuhan energi sudah tercukupi maka konsumsi ransum akan menurun. Hal ini sesuai dengan pendapat Anggorodi (1985) yang menyatakan bahwa jumlah konsumsi ransum sangat ditentukan oleh kandungan energi dalam ransum, apabila kandungan energi dalam ransum tinggi maka konsumsi ransum akan turun dan sebaliknya apabila kandungan energi ransum rendah, maka konsumsi ransum akan naik guna memenuhi kebutuhan energi.

\section{Pertambahan Bobot Badan Harian}

Hasil analisis variansi menunjukkan bahwa suplementasi minyak ikan lemuru dan $L$-karnitin dalam ransum berpengaruh sangat nyata $(\mathrm{P}<0,01)$ terhadap pertambahan bobot badan harian. Nilai pertambahan bobot badan harian P0, P1 dan P2 adalah sebagai berikut 23,85; 25,22 dan 26,48 g/ekor/hari. Pertambahan bobot badan harian yang paling rendah ditunjukkan pada perlakuan kontrol (P0) 23,85 g/ekor/hari. Hasil uji lanjut kontras orthogonal menunjukkan bahwa perlakuan suplementasi minyak ikan lemuru sebesar $4 \%$ pada (P1 dan P2) secara statistik berpengaruh sangat nyata terhadap perlakuan $\mathrm{P} 0$ $(\mathrm{P}<0,01)$, hal ini menunjukkan bahwa suplementasi minyak ikan lemuru sebesar $4 \%$ mampu meningkatkan nilai pertambahan bobot badan harian sebesar 25,22 g/ekor/hari. Lebihnya kualitas ransum P1 dan P2 jika dibandingkan dengan ransum P0 terbukti dapat menaikkan pertambahan bobot badan harian dikarenakan tingginya kandungan energi dalam ransum $\mathrm{P} 1$ dan P2 mampu mencukupi kebutuhan energi yang diperlukan ternak untuk hidup pokok dan produksi.

Penggunaan $L$-karnitin sebesar 30 ppm pada (P2) memberikan pengaruh signifikan yang berbeda sangat nyata terhadap perlakuan P0 dan berbeda nyata terhadap P1, hal ini menunjukkan bahwa penambahan $L$-karnitin yang dikombinasikan dengan $4 \%$ minyak lemuru mampu membantu metabolisme tubuh ternak untuk membentuk energi lebih cepat yang dapat dimanfaatkan oleh tubuh untuk mencukupi kebutuhan hidup pokok dan produksi, hal ini sependapat dengan Owen et al. (2001) yang menyatakan bahwa $L$-karnitin dapat meningkatkan digestible nutrient dan membantu metabolisme yang diperlukan untuk mengoksidasi asam lemak rantai panjang dalam mitokondria, sehingga nutrien yang dicerna ternak dapat menghasilkan pertambahan bobot badan yang optimal. Peran $L$-karnitin pada ransum (P2) begitu penting didalam membantu proses metabolisme dalam tubuh ternak Chatzifotis dan Takeuchi (1997) menyatakan bahwa $L$-karnitin mempunyai potensi yang baik untuk meningkatkan pertumbuhan dan katabolisme lemak. Didukung dengan pendapat lain yang menyatakan pada penelitian terdahulu dengan menggunakan minyak ikan lemuru dan $L$ karnitin pada induk ayam pedaging menunjukkan hasil berpengaruh nyata terhadap produksi (Abadi et al., 2007), hal ini sesuai dengan penelitian yang dilakukan bahwa perlakuan P1 terhadap perlakuan P2 setelah diuji lanjut menunjukkan hasil berpengaruh nyata $(\mathrm{P}<0,05)$. Pemanfaatan protein untuk pertumbuhan begitu optimal dengan adanya $L$-karnitin dalam ransum (P2), suplementasi minyak ikan yang mengandung $L$ karnitin dapat membantu proses pembentukan energi dan penghematan protein ransum, sehingga energi dari protein dapat digunakan untuk pertumbuhan. Menurut Arslan (2006) bahwa pemberian $L$-karnitin dalam ransum dapat meningkatkan aksi protein sparing effect dari lemak, sehingga energi dari protein sebagian besar digunakan untuk pertumbuhan.

\section{Konversi Ransum}

Hasil analisis variansi menunjukkan bahwa suplementasi minyak ikan lemuru dan $L$-karnitin dalam ransum berpengaruh sangat nyata $(\mathrm{P}<0,01)$ terhadap konversi ransum. Angka konversi ransum tertinggi pada perlakuan ransum kontrol (P0) sebesar 6,02, sedangkan angka konversi terendah ditunjukkan pada perlakuan suplementasi minyak ikan lemuru (P1) sebesar 5,55 dan pada perlakuan suplementasi minyak ikan lemuru yang ditambah $L$-karnitin $30 \mathrm{ppm}$ (P2) sebesar 5,26. Hasil uji lanjut kontras orthogonal menunjukkan bahwa P0 terhadap P1 dan $\mathrm{P} 2$ berpengaruh sangat nyata $(\mathrm{P}<0,01)$, sedangkan $\mathrm{P} 1$ terhadap $\mathrm{P} 2$ berpengaruh nyata 
$(\mathrm{P}<0,05)$. Feed Convertion Ratio $(\mathrm{FCR})$ atau rasio konversi ransum merupakan satuan untuk menghitung efisiensi ransum pada budidaya pembesaran dan penggemukan. Dengan menghitung FCR dari ternak akan sangat membantu kita di dalam mengefisienkan ransum yang akan kita gunakan. Hasil perhitungan FCR dengan angka yang kecil berarti ransum yang diberikan tersebut semakin bagus. FCR didefinisikan berapa jumlah kilogram pakan yang dibutuhkan untuk menghasilkan satu kilogram berat badan bagi ternak

Konversi ransum dipengaruhi oleh kandungan energi pada ransum. Kandungan energi yang tinggi pada ransum yang disuplementasi minyak ikan 4\% menjadikan peningkatan efisiensi penggunaan ransum. Menurut Lestari (2001), peningkatan kuantitas lemak ransum mengakibatkan ransum digunakan dengan sangat efisien, kadar lemak mengakibatkan peningkatan nilai retensi lemak dalam ransum, adanya retensi lemak yang berbeda menyebabkan efisiensi ransum yang berbeda pula.

Farrel (1995) melaporkan bahwa penggunaan omega-3 dalam ransum ayam akan menurunkan konsumsi dan konversi ransum dibanding dengan ransum komersial. Pengaruh berbeda sangat nyata terhadap konversi ransum, menunjukkan bahwa suplementasi minyak ikan lemuru menyebabkan perbedaan efisiensi penggunaan ransum oleh itik. Hal ini terjadi karena respon terhadap pertambahan bobot badan harian yang juga signifikan, sehingga secara langsung akan membedakan tingkat konversi ransum. Perbedaan kandungan energi dalam ransum memberikan respon yang berbeda terhadap FCR yang dihasilkan, ransum P1 memiliki kandungan energi sebesar 3037,09 ME kcal/kg lebih tinggi jika dibandingkan energi P0 yang sebesar 2705,89 ME $\mathrm{kcal} / \mathrm{kg}$, menurut Subiharta et al. (1995) bahwa peningkatan kandungan protein dan energi dalam ransum akan meningkatkan level efisiensi ransum.

Suplementasi minyak ikan lemuru yang kaya akan energi dapat memberikan keuntungan pemanfaatan energi dalam ransum tanpa merombak energi dari protein, perbaikan pertumbuhan, efisiensi ransum serta penyerapan nutrien yang optimal dikarenakan ransum dengan suplementasi minyak ikan mengandung gizi yang lebih baik. Hal ini sesuai dengan pendapat
Sanyoto dan Riyanto (2004) yang menyatakan bahwa penambahan minyak dan lemak memberikan keuntungan efek kalori ekstra yang ditunjukkan dengan tingginya pemanfaatan energi dalam ransum, perbaikan pertumbuhan dan efisiensi penggunaan ransum. Ransum yang mengandung serat kasar yang lebih rendah dan kadar energi metabolis yang tinggi tidak mengherankan jika ransum dengan tingkat kepadatan gizi tinggi menghasilkan efisiensi/konversi ransum yang lebih baik. Leeson et al. (1996) dan Hussein et al. (1996) melaporkan bahwa semakin tinggi kadar energi dan protein dalam ransum, maka konversinya akan semakin baik disebabkan konsumsi ransum lebih rendah.

Perlakuan suplementasi minyak ikan lemuru 4\% yang dikombinasikan dengan $L$-karnitin 30 ppm (P2) menunjukkan hasil yang juga signifikan. Pemberian $L$-karnitin dapat meningkatkan digestibilitas nutrien pada ternak, sehingga ransum yang diberikan dapat terserap optimal oleh ternak untuk pertumbuhan, hal ini terbukti karena adanya respon terhadap pertambahan bobot badan harian yang juga signifikan, sehingga secara langsung akan membedakan tingkat konversi ransum.

\section{Income Over Feed Cost (IOFC)}

Income Over Feed Cost (IOFC) adalah selisih total pendapatan dengan biaya ransum yang digunakan selama usaha penggemukan ternak. IOFC ini merupakan barometer untuk melihat seberapa besar biaya ransum yang merupakan biaya terbesar dalam usaha penggemukan ternak. Hasil penelitian menunjukkan nilai Income Over Feed Cost selisih dari total pendapatan dengan total biaya ransum digunakan selama penelitian pada perlakuan P0, P1 dan P2 adalah Rp5.084,1; Rp6.781,7 dan Rp8.294,4. Nilai penerimaan akhir diperoleh dari bobot badan akhir itik dikalikan dengan harga jual itik/ kg menurut harga pasar pada bulan November 2015, sementara itu nilai pengeluaran total didapatkan dari nilai FCR itik dikalikan dengan besarnya harga/biaya ransum tiap perlakuan. Biaya ransum tertinggi yaitu pada perlakuan P2 karena adanya tambahan biaya minyak ikan lemuru serta $L$-karnitin. Faktor yang berpengaruh penting dalam perhitungan IOFC adalah pertambahan bobot badan selama penggemukan, konsumsi ransum dan harga ransum. 
Tabel 5. Income Over Feed Cost

\begin{tabular}{lrrr}
\hline \multirow{2}{*}{ Uraian } & \multicolumn{3}{c}{ Perlakuan } \\
\cline { 2 - 4 } & \multicolumn{1}{c}{ P0 } & \multicolumn{1}{c}{ P 2} \\
\hline Penerimaan Akhir (Rp) & $35.394,77$ & $36.390,96$ & $37.145,46$ \\
Pengeluaran Total Biaya Pakan (Rp) & $30.310,70$ & $29.609,25$ & $28.851,10$ \\
IOFC (Rp) & $5.084,10$ & $6.781,70$ & $8.294,40$ \\
\hline
\end{tabular}

Keterangan:

Harga jual itik Rp35.000,00/ kg bobot hidup

Biaya ransum $/ \mathrm{kg} \quad \mathrm{P} 0=\mathrm{Rp} 5.035,00$

$\mathrm{P} 1=\mathrm{Rp} 5.335,00$

$\mathrm{P} 2=\mathrm{Rp} 5.485,00$

Pertumbuhan yang baik belum tentu menjamin keuntungan maksimum, tetapi pertumbuhan yang baik dan diikuti dengan konversi ransum yang baik serta biaya ransum yang minimal akan mendapatkan keuntungan yang maksimal pula. Tingginya nilai IOFC pada perlakuan (P2) menunjukkan bahwa ransum yang digunakan memberikan tinggat efisiensi yang paling tinggi jika dibandingkan dengan P0 dan P1.

Tingkat efisiensi yang tinggi berarti ransum yang digunakan memiliki kualitas yang tinggi pula. Hal ini sesuai dengan pendapat Rasyaf (2007) yang menyatakan apabila dikaitkan dengan pegangan berproduksi dari segi teknis maka dapat diduga bahwa semakin efisien ternak mengubah zat makanan menjadi daging maka semakin baik pula IOFC yang didapatkan. Selisih harga ransum pada setiap perlakuan disebabkan karena terdapatnya penambahan minyak ikan dan $L$-karnitin. Rata -rata selisih harga ransum yang diberi perlakuan yaitu $( \pm$ Rp. $150,-/ \mathrm{kg})$. Amrullah (2004) menyatakan bahwa mahalnya harga ransum akan menurunkan pendapatan peternak. Jika ditinjau dari hal tersebut maka penggunaan minyak ikan lemuru dan $L$-karnitin lebih efisien, meskipun biaya ransum yang dikeluarkan lebih tinggi tetapi produksi yang dihasilkan lebih optimal.

\section{KESIMPULAN DAN SARAN}

\section{Kesimpulan}

Berdasarkan hasil penelitian dapat diambil kesimpulan bahwa suplementasi minyak ikan lemuru 4\% dan $L$-karnitin $30 \mathrm{ppm}$ dapat menurunkan konsumsi ransum dan konversi ransum serta dapat menaikkan pertambahan bobot badan harian dan IOFC itik lokal jantan.

\section{Saran}

Saran dari penelitian ini adalah suplementasi minyak ikan lemuru $4 \%$ dan $L$-karnitin $30 \mathrm{ppm}$ dapat dilakukan pada ransum itik lokal jantan.

\section{DAFTAR PUSTAKA}

Abadi, G.S.H., Rahimi, SH., Kamali, M.A., \& Torshizi, K.M.A. 2007. Effects of two dietary levels of L-carnitine and vegetable fat powder on quality of cockerels sperm, and fertility and hatchability in broiler breeders. Journal of Veterinary Research. 62(3), 107-114.

Amrullah, I.K. 2004. Nutrisi Ayam Broiler. Seri Beternak Mandiri. Lembaga Satu Gunungbudi, Bogor.

Anggorodi. 1985. Kemajuan Mutakhir dalam Ilmu Ternak Unggas. Jakarta: Universitas Indonesia Press,

Arslan, C. 2006. L-carnitine and its use as a feed Additive in Poultry Feeding a Review. Departement of Animal Nutrition. 157(3), 134142.

Chatzifotis, S., \& Takeuchi, T. 1997. Effect of supplemental carnitine on body weight loss, proximate and lipid compositions and carnitin content of Red Sea Bream (Pagrus major) during starvation. Aquaculture. 158(1-2), 129140.

Estiasih, T. 1996. Mikroenkapsulasi Konsentrat Asam Lemak $\Omega-3$ dari Limbah Cair Pengalengan Ikan Lemuru (Sardinella longiceps) (Thesis). Program Pasca Sarjana, Jurusan Magister Ilmu ternak Universitas Gadjah Mada, Yogyakarta.

Farrell, D.J. 1995. The Heart Smart Egg : Why It is Good for You. Proceedings The $2^{\text {nd }}$ Poultry 
Science Symposium of WPSA Indonesian Branch. p: 10-20.

Hussein, A.S., Cantor, A.H., Pescatore, A.J., \& Johnson, T. H. 1996. Effect of dietary protein and energy levels on pullet development. Poult.Sci. 75(8), 973-978.

Lesson, S., Caston, L., \& Summers, J.D. 1996. Broiler response to energy or energy and protein dilution in the finisher dict. Poult. Sci. 75(4), 522-528.

Lestari, S. 2001. Pengaruh Kadar Ampas Tahu yang Difermentasi terhadap Efisiensi Pakan dan Pertumbuhan Ikan Mas (Cyprinus carpio) (Skripsi S1). Prodi Budidaya Perairan IPB, Bogor.

Owen, K.Q., Ji, H., Maxwell, C.V., Nelssen, J.L., Goodband, R.D., Takach, M.D., Tramblay, G.C., \& Koo, S.I. 2001. Dietary L-carnitne suppresses mitochondrial branched-chain keto acid dehydrogenase activity and enhances protein accretion and carcass characteristic of swine. Journal of Animal Sciene. 79, 31043112.

Rasyaf, M. 2007. Beternak Ayam Pedaging. Cetakan ke-27. Jakarta: PT. Penebar Swadaya.

Sanyoto, J.L., \& Riyanto, J. 2004. Penggunaan minyak kelapa dan lemak sapi sebagai sumber energi ransum broiler. Journal of the Indonesian Tropical Animal Agriculture. 29(3), 148-155.

SNI (Standar Nasional Indonesia). 2006. Pakan Itik Bertelur (duck layer). SNI 01-3910-2006. Badan Standardisasi Nasional.

Steel, R.G.D., \& Torrie, J.H. 1995. Prinsip dan Prosedur Statistika. Terjemahan B.Sumantri. Jakarta: PT Gramedia Utama.

Subiharta, D.M. Yuwono. D. Muryanto, A.P. Sinurat, \& Wartiningsih. 1995. Pengaruh Peningkatan Kualitas Pakan dan Efisiensi Perusahaan pada Penampilan dan Efisiensi Perusahaan pada Itik Tegal yang Dipelihara Secara Intensif. Proc. The $2^{\text {nd }}$ Poulty Science Symposium of The Word's Poultry science Association. Semarang. Jawa Tengah. 